\title{
269 頭頸部に対する放射線照射領域内に発生した二次癌症例の検討
}

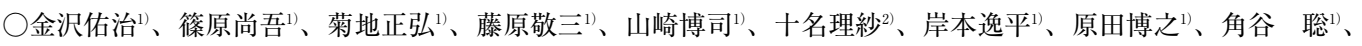
宇佐美 悠 ${ }^{3}$ 、今井幸弘 ${ }^{3}$ 、内藤 泰 ${ }^{11}$

神戸市立医療センター中央市民病院 耳鼻咽喉科・頭頸部外科 ${ }^{11}$ 、先端医療センター 耳鼻咽喉科 ${ }^{2}$ 、

神戸市立医療センター中央市民病院＼cjkstart臨床病理科 ${ }^{3)}$

1988年から2006年までに頭頸部に放射線治療を行った頭頸部癌および悪性リンパ腫患者のなかで放射線照射領域内に二次 癌を発症した14名の患者について、その臨床的、病理組織学的特徵を検討した。一次癌は喉頭癌 8 例、上咽頭癌 2 例、口腔 癌 2 例、中咽頭癌 1 例、上顎癌 1 例であった。全例に遠隔転移はみられなかった。二次癌の発生部位は下咽頭 8 例、中咽頭 3 例、口腔 2 例であった。二次癌は 13 例で N0M0、1 例で $\mathrm{N} 2 \mathrm{bM} 0$ であった。病理組織について、全例で一次癌、二次癌と もに扁平上皮癌であったが、1例で二次癌標本組織内に肉腫成分を伴っていた。二次癌全例に対して手術を行った。二次癌 発見後の経過観察期間は 0-112力月（平均33.3力月）で、10例は無再発生存しており、2 例は原病死、1 例は他病死、2 例 は担癌生存している。リンパ節転移が少ない傾向がみられ、局所進行癌でも局所制御さえ可能であれば、長期生存を得られ ている症例もみられた。放射線誘発癌は予後不良であるとの報告もあるが、局所の制御さえ可能であれば比較的予後良好で ある可能性が示唆された。

\section{0}

\section{メニエール病難治例に対するパイリング治療}

○青木光広、若岡敬紀、出原啓一、林 寿光、久世文也、水田啓介、伊藤八次 岐阜大学 医学部 耳鼻咽喉科

【目的】メニエール病間歇期における治療の目的は、めまい発作頻度の減弱と聴力悪化防止である。しかし、プラシボ効 果を有意に優るものはいまだない。そこで、従来の内服治療に抵抗するメニエール病難治例に対して、パイリング治療でい かに対応できるか検討した。【方法】症例はメニエール病難治例13名である（男性 7 名、女性 6 名、平均年齢 60.3 歳）。治療 前 6 カ月の発作頻度は18.5回で、難聴耳の平均聴力レベル（4 分法）は $41.3 \mathrm{~dB}$ であった。2 週間ごとに評価し、めまい発 作が一度でもあれば、次の治療を積み重ねていくパイリング治療を施行した。【結果】全例に苓桂术甘湯とストレス回避の 生活指導を行い、改善しなかった 7 名には、デキサメタゾン $(1 \mathrm{mg})$ を投与した。それでも改善がなかった 4 名には、さら に鼓膜チューブ留置を行い、効果がなかった 2 名には中耳加圧療法を追加導入した。治療後平均観察期間は 12.8 月である が、全例でめまい発作は認めていない。聴力は有意な改善はなかった。【結論】本治療法は難治性メニエール病症例には有 効と思われた。

\section{1 一側性メニエール病における聴力低下時の頭振り眼振所見と聴力の短期予後の関係}

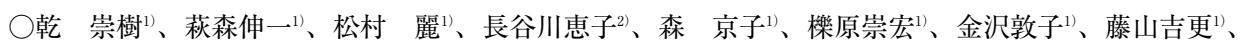
荒木倫利 ${ }^{133}$ 、河田 了 $^{1}$

大阪医科大学 耳鼻咽㑨科・頭頸部外科 ${ }^{12}$ 、大阪府済生会中津病院 耳鼻咽喉科・頭頸部外科 ${ }^{2)}$ 、 洛和会 音羽病院 耳鼻咽喉科・頭頸部外科 ${ }^{3)}$

頭振り眼振（head shaking nystagmus：以下 HSN）は末梢性疾患においては麻痺性（健側向き）の HSN をみとめること が多いが、内リンパ水腫では刺激性（患側向き）の HSN が見られる割合が増加するとされる。

今回われわれは、過去 5 年間に当科で加療を行った一側性メニエール病患者 115 例を対象とし、聴力低下時に誘発される HSN 所見と、その後 6 カ月以内の聴力予後とに関係があるかの検討を行った。HSN は CCD カメラを用いない Frenzel 眼 鏡で観察し、聴力評価は日本めまい平衡医学会によるメニエール病の効果判定基準に準じた。

その結果、刺激性 HSN 群が23例、麻痺性 HSN 群が22例、HSN なし群が70例であった。経過については、麻痺性 HSN 群は HSN なし群に比べて有意に聴力改善例の割合が少なかった。他の群間比較では聴力改善例の割合に有意差は無かっ た。

以上の結果からメニエール病において、聴力低下時に認める麻痺性の HSN は、短期での聴力の予後不良を示唆する所見 であると考えられた。

\section{2 内リンパ水腫手術後のめまい発作完全抑制症例に関する検討}

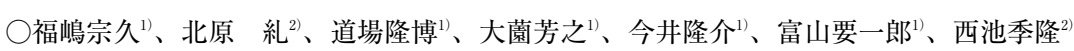

大阪労災病院 耳鼻咽喉科 ${ }^{11}$ 、大阪大学医学部 耳鼻咽喉科・頭頸部外科 ${ }^{2}$

はじめに）内リンパ囊開放術による治療効果としてめまい発作完全抑制を達成した症例の内耳の状態を把握するために、 今回われわれはめまい成績と他の神経耳科学的検査所見の相関について検討を行った。対象） 97 年から01年までの 5 年間に 当施設で手術施行されその後 2 年間経過観察が可能であった 52 症例。検討項目) 手術前・手術後の月平均めまい発作頻度、 温度刺激検査における最大緩徐相速度、最悪平均聴力レベル、グリセロールテスト。結果）術後のめまいが完全抑制された か否かと、最大緩徐相速度改善・維持は相関せず、グリセロールテスト陰性化も相関しない。術後のめまいが完全抑制され たか否かと聴力改善は相関がないが、聴力改善・維持とは相関がある。考察）内リンパ霊開放術後のめまい発作完全抑制 は、必ずしも前庭機能改善や水腫軽減の上に成り立っているわけではない。内リンパ裹開放術後のめまい発作完全抑制が必 ずしも聴力改善を導くとは限らないが、間接的効果で聴力の改善・維持される症例があると考える。 


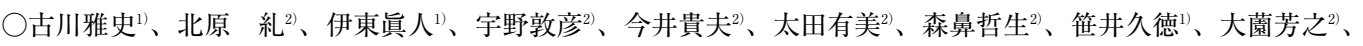
猪原秀典 ${ }^{2}$ 、堀井 新 ${ }^{3)}$

関西労災病院1)、大阪大学医学部耳鼻咽喉科・頭頸部外科 ${ }^{2} 、$ 市立吹田市民病院耳鼻咽喉科 ${ }^{3}$

難治性メニエール病（以下難メ病）において神経症、うつ傾向の占める割合を検索し、めまい・難聴の治療成績に与える 心理面の影響を検討した。対象は過去 12 年間に、CMI 健康調査票およびSDS うつスコアに回答し、治療後 2 年以上経過観 察し得た難メ病263例で、うち内リンパ震手術207例、非手術56例とした。CMI 領域 III、IV 神経症、SDS スコア40点以上 をうつ傾向と診断した。また、治療後 2 年でめまい発作消失かつ聴力改善 $10 \mathrm{~dB}$ 以上を達成した症例を著効群、その他を非 著効群とした。

手術治療に関して、精神疾患を合併しない難メ病は精神疾患を合併する難义病に比して、統計学的に有意に良好であっ た。さらに、精神疾患を合併する難义病手術例の成績でも、精神疾患を合併しない難义病非手術例に比して、統計学的に有 意に良好であった。

以上のことから難メ病が精神疾患を伴う場合、1．精神疾患治療を行うことは手術治療を行う場合でも予後を改善させる ために必要である、2. 保存治療に精神疾患治療を併行してもなお手術治療を必要とする症例は存在する、可能性が示唆さ れた。

\section{4 メニエール病と耳管機能の関係}

○扇 和弘 ${ }^{1)}$ 、真鍋恭弘 ${ }^{1}$ 、木村幸弘 ${ }^{2}$ 、藤枝重治 ${ }^{2)}$

真生会富山病院 耳鼻咽喉科 ${ }^{11}$ 、福井大学 医学部 耳鼻咽喉科頭頸部外科 ${ }^{2)}$

メニエール病と耳管機能の関係についての報告は少ない。難治性メニエール病に対する中耳加圧療法を行う際に鼓膜チュ ーブ挿入術を行うだけで改善する症例があることはよく知られている。しかしその機序は明らかではない。われわれは難治 性メニエール病の症例の中に耳管機能不全を示す症例が存在し、そうした症例に鼓膜チューブ挿入術の効果があるのかもし れないと推測した。今回メニエール病と耳管機能の関倸について調査したので報告する。メニエール病確実例の耳管機能を 検査した。耳管機能検査機を使用し、検査には音響法を用いた。結果を健常人のデー夕と統計的に比較すると、メニエール 病の中には耳管機能不全を示す症例がいくつか存在した。そのタイプは狭窄型だけでなく開放型も存在した。加えてメニエ 一ル病難治例においてその傾向は顕著であった。耳管機能不全がメニエール病の発症と関連している可能性が示唆された。 しかし耳管機能検査の結果の評価は簡単ではなく、診断には注意が必要であると考えられた。

\section{5 良性発作性頭位めまい症における聴力についての検討}

○樫葉恵子 ${ }^{1)}$ 、瀨尾 徹 ${ }^{2}$ 、坂 直樹 ${ }^{3)}$ 、足達 治 ${ }^{11}$ 、美内慎也 ${ }^{11}$ 、阪上雅史 ${ }^{3}$

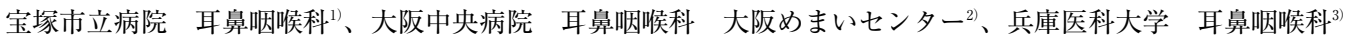

【はじめに】良性発作性頭位めまい症（BPPV）は聴力に異常を認めないことが多いとされる。しかし時に聴力に左右差 を認める症例に遭遇することがある。今回 BPPV 症例の患側と初診時聴力の関係について検討を行った。

【対象と方法】耳疾患の既往がなく眼振所見より一側性良性発作性頭位めまい症と診断した93名である。純音聴力検査は 3 分法聴力、低音部聴力、高音部聴力に扔いて評価し、健側と患側の聴力が $5 \mathrm{~dB}$ 以上の差を差があると判断した。

【結果】症例数は 3 分法聴力、低音部聴力、高音部聴力いずれも差がないものが最も多く、患側が低下したものは健側が 低下したものより多い傾向があった。眼振消失までの平均日数は、患側が低下したもの、健側が低下したもの、差がなかっ たものの間で有意差は認めなかった。

【結論】BPPVの初診時聴力は患側低下のものが少なくなかった。脱落した耳石が BPPVを引き起こすと考えられている が、BPPVに何らかの蝸牛障害も併発したのか、あるいは耳石の脱落が聴力に影響を与えたのかが考えられた。

\section{6 外側半規管型頭位めまい症の検討}

○書間＼cjkstart清、渡部涼子、留守卓也、三橋敏雄

都立駒込病院 耳鼻咽喉科・頭頸部腫瘍科

外側半規管型頭位性眼振は眼振の方向によって方向交代性上向性眼振と下向性眼振とに分類される。これらは眼振が 1 分 以上続く持続型で、現在のところ上向性についてはクプラ結石症、下向性に関しては、直接的な証明は未だに不可能ではあ るが “軽いクプラ (light cupula)”が想定されている。一方で、眼振が30秒程度で 1 分を超えない、減衰型の方向交代性下 向性眼振があり、原因として管内耳石が考えられ、その治療に Lempert 法などの浮遊耳石置換法が用いられ良好な成績を 得ている。しかし、一條による外側半規管型頭位めまい症の分類（耳鼻臨床、2008）では減衰型で上向性の眼振の記載がな い。減衰型の方向交代性上向性眼振は病態として、耳石が患側の外側半規管の前部管脚内を流動する場合が考えられるが、 当科で経験した症例では、方向交代性下向性眼振を経ないで治癒していることから卵形襄側膨大部内の浮遊耳石が原因とし て考えられた。外側半規管型頭位めまい症の分類につき再検討したので報告する。 